Submitted 02.10.2015. Approved 07.21.2015

Evaluated by double blind review process. Scientific Editor: Paulo Roberto Barbosa Lustosa

DOI: http://dx.doi.org/10.1590/So034-759020160107

\title{
THE ROLE OF EARNINGS PERSISTENCE IN VALUATION ACCURACY AND THE TIME HORIZON
}

\author{
O papel da persistência dos lucros na acurácia de avaliação e no horizonte \\ temporal
El rol de la persistencia de las ganancias en la exactitud de la valoración y el horizonte temporal

\begin{abstract}
Based on the assumption that earnings persistence has implications for both financial analysis and compensation contracts, the aim of this paper is to investigate the role of earnings persistence assuming that (i) more persistent earnings are likely to be a better input to valuation models and (ii) more persistent earnings are likely to serve as a proxy for long-term market and managerial orientation. The analysis is based on Brazilian listed firms from 1995 to 2013, and while we document strong support for the relevance of earnings persistence in financial analysis and valuation, we fail to document a significant relationship between earnings persistence and long-term value orientation. These results are sensitive to different specifications, and additional results suggest that firms' idiosyncratic risk (total risk) is relevant to explain the focus on short-term outcomes (short-termism) across firms. The main contribution of this paper is to offer empirical evidence for the relevance of accounting numbers in both valuation and contractual theories in an emergent market.
\end{abstract}

KEYWORDS | Accounting information, earnings persistence, residual income valuation, market myopia, emerging markets.

\section{RESUMO}

Com base no pressuposto de que a persistência dos lucros tem implicações para análise financeira e elaboração de contratos de incentivo, o objetivo deste artigo é investigar o seu papel ao considerar que lucros mais persistentes provavelmente são (i) uma informação melhor para modelos de avaliação e (ii) uma medida para capturar orientação de longo prazo da firma. A análise utiliza dados de empresas que possuem ações negociadas na BM\&F BOVESPA no período entre 1995 e 2013. Os resultados oferecem evidências que suportam a relevância da persistência dos lucros na análise e avaliação financeiras; entretanto, não oferecem suporte para o relacionamento entre persistência dos lucros e orientação de longo prazo. Esses resultados se mantêm mesmo diante de diferentes especificações; além disso, análises adicionais sugerem que o risco idiossincrático de uma firma (risco total) é relevante para explicar o foco em resultados financeiros de curto prazo (short-termism) entre as firmas observadas. A principal contribuição deste artigo é oferecer evidências empíricas relativas à relevância dos números contábeis em modelos de avaliação e na teoria dos contratos em um mercado emergente.

PALAVRAS-CHAVE I Informação contábil, persistência dos lucros, avaliação pelos lucros residuais, miopia de mercado, mercados emergentes.

\section{RESUMEN}

En base al supuesto de que la persistencia de las ganancias tiene implicancias tanto en el análisis financiero como en los contratos de compensación, el objetivo de este trabajo es investigar el rol de la persistencia de las ganancias, asumiendo que (i) es probable que las ganancias más persistentes constituyan un mejor aporte a los modelos de valoración y (ii) las ganancias más persistentes tienen más posibilidades de funcionar como una aproximación al mercado de largo plazo y a la orientación gerencial. El análisis se basa en empresas que cotizan en bolsa en Brasil desde 1995 hasta 2013 y si bien documentamos un sostenido apoyo a la relevancia de la persistencia de los ingresos en el análisis financiero y la valoración, no hemos podido documentar una relación significativa entre la persistencia de las ganancias y la orientación de valor a largo plazo. Estos resultados son sensibles a diferentes especificaciones y otros resultados sugieren que el riesgo idiosincrásico de las empresas (riesgo total) resulta relevante para explicar la atención centrada en los resultados de corto plazo (cortoplacismo) entre las diversas empresas. El aporte principal de este trabajo consiste en brindar evidencia empírica de la importancia de los números contables tanto en la valoración como en las teorías contractuales, en un mercado emergente.

PALABRAS CLAVE I Información contable, persistencia de las ganancias, valoración de ingresos residuales, miopía de mercado, mercados emergentes. 


\section{INTRODUCTION}

Managers and stock market agents have been blamed for overweighing near-term earnings to the detriment of creating longrun value. The accounting and financial literature has dedicated a great deal of attention to so-called myopic behavior or shorttermism. Specifically, the literature can be divided into two complementary approaches, one focusing on managerial myopia (Dikolli \& Vaysman, 2006; Marginson \& McAulay, 2008; Sliwka, 2002) and the other on market myopia (Black \& Fraser, 2002; Davies, Haldane, Nielsen, \& Pezzini, 2014; Miles, 1993). Some studies attempted to link the two approaches by showing that managerial myopia can be explained by stock market pressure (Bhojraj \& Libby, 2005; Demirag, 1995; Laverty, 1996; Samuel, 2000). In other words, managers try to maximize firms' stock price and comply with stock market short-term expectations.

To prevent managers from taking actions that sacrifice longterm performance for short-term outcomes, Baber, Kang, and Kumar (1998) claim that earnings persistence plays a significant role as a contractual instrument that monitors managers' shortterm orientation. As a consequence, earnings persistence should play, at the same time, two relevant roles, one in the equity market, as a valuation input, and one in compensation decisions as a measure of the time horizon (Dechow, Ge, \& Schrand, 2010).

The aim of this paper is to decompose firm value and to analyze the role of earnings persistence in valuation accuracy and as a proxy for long-term market orientation in the Brazilian market. Thus, we assume that earnings persistence has two main implications for financial analysis and the contractual role of accounting numbers: more persistent earnings are likely (i) to be a better input to valuation models and (ii) to serve as a proxy for long-term market and managerial orientation; as a consequence, the weight of long-term performance will be higher for firms with higher earnings persistence.

Using a sample consisting of 176 Brazilian listed firms from 1995 to 2013, we decompose firm value into three componentsbook value, short-term earnings, and long-term 'terminal value'-and assess the relevance of earnings persistence in producing more accurate firm value estimates and the association of earnings persistence with long-term value components.

This paper contributes to the literature by offering empirical evidence for the relevance of accounting numbers in both valuation and contractual theories in an emergent market that is characterized by concentrated corporate structures and high interest rates, which in turn can strongly affect the time orientation of market agents.

The remainder of this paper is organized as follows. Conceptual framework reviews the relevant accounting literature and develops the empirical model. After that, we present our data sample. Then, we introduce the empirical findings and discuss the results. Finally, we offer some concluding remarks and suggestions for future research.

\section{CONCEPTUAL FRAMEWORK AND MODEL SPECIFICATION}

Empirical studies have examined the myopic behavior of listed firms in the United Kingdom (U.K.) and United States (U.S.). For instance, Davies et al. (2014), Miles (1993) and Nickell and Wadhwani (1987) offer evidence that the U.K. and/or U.S. stock markets systematically underprice short-term outcomes relative to long-term value components. In this regard, Bushee (1998, 2001) investigates whether the type of stockholder is a cause of managerial myopia that is the result of pressure placed on managers to meet short-term earnings goals.

Few studies have tested stock market myopia outside the U.K. and U.S. stock markets. One exception is the study developed by Black and Fraser (2002), which comprises the stock markets of Germany, Australia, the U.S., Japan and the U.K., and examines if these stock markets underestimated long-term cash flows and overestimated short-term cash flows during the period from 1973 to 1999 . The results indicate the mispricing hypothesis, especially for the U.K. stock market.

Of particular importance is how these studies evaluate firm value to infer if the stock market is myopic. Three competing approaches are the discounted cash flow, dividend discount, and accounting-based valuation models. The discounted cash flow and dividend discount models have been criticized for imposing restrictive assumptions, such as the relationship between earnings and dividends or cash flows (Abarbanell \& Bernard, 2000; Feltham \& Ohlson, 1999). In the case of an accountingbased valuation model, the restrictions used to implement the first two valuation models are in part not required as long as the premise of clean surplus relation applies.

The general residual income valuation (RIV) model (Ohlson, 1995) suggests that a firm's equity value $(P)$ equals its contemporary accounting valuation, captured by the book value of equity $(b)$ at time $t$, adjusted by the present value of future abnormal earnings, as shown in Equation 1:

$$
P_{l}=b_{t}+\sum_{\tau=1}^{\omega}(1+r)^{-\tau} E_{t}\left[\mathrm{X}_{t+\tau}-r b_{t+\tau-1}\right]
$$

where $P_{t}$ and $b_{t}$ are the market price and the book value of equity, respectively, at time $t . X_{t+\tau}$ is the earnings for period $t+\tau$, and $r$ is a discount rate. Thus, the abnormal earnings are defined 
as the difference between reported earnings and accretion of discount $\left(x_{t+\tau}-r b_{t+\tau-1}\right)$, where accretion of discount is cost of capital times opening book value. The general model presented in Equation 1 makes it explicit that abnormal earnings are generated for a non-defined period of time (perpetuity).

To describe the empirical tests of stock market myopia, the following discussion relies heavily on Abarbanell and Bernard (2000) in decomposing the term-structure components of the RIV model. Specifically, by modifying Equation 1 and defining an explicit projection period $T$, the expected excess of price over book value for time $T, E_{\tau}\left[P_{T}-b_{T}\right]$, is equal to the discounted abnormal earnings for years beyond $T$; thus:

$$
E_{t}\left[P_{T}-b_{T}\right]=\sum_{t=T+1}(1+r)^{-(t-T)} E_{t}\left[x_{t}\right.
$$

Combining Equation 2 and 1 yields an empirical model in which three components are used to estimate firm value. The first one is the book value at time $t$, the second term is the discounted abnormal earnings for the next $T$ years, and the last term reflects abnormal earnings to be generated after $T$ years (the expected excess of price over book value for time $T$ ).

$$
P_{t}=b_{t}+\sum_{\tau=1}^{1}(1+r)^{-\tau} E_{t}\left[X_{1+\tau}-r b_{t+\tau-1}\right]+(1+r)^{-T} E_{t}\left[P_{t+T}-b_{t+T}\right]
$$

Hence, Equation 3 decomposes firm value into three components that derive from the current book value and the earnings to be generated at different points on the time horizon (up to and after $T$ ). Particularly, it estimates a near term defined by period $T$ and a long term representing later years. Abarbanell and Bernard (2000) claim that the extent of departures of actual market prices from those implied by Equation 3 can be assessed with the following cross-sectional regression:

$$
P_{j t}=\alpha_{0}+\alpha_{1} b_{t}+\alpha_{2} \sum_{\tau=1}^{1}(1+r)^{-\tau} E_{t}\left[X_{t+\tau}-r b_{t+\tau-1}\right]+\alpha_{3}(1+r)^{-T} E_{t}\left[P_{t+T}-b_{t+T}\right]+\omega_{j t}
$$

Based on Equation 4, myopic stock market behavior is implied if the book value coefficient and/or the short-term earnings coefficient are significantly above one $\left(a_{1}>1 ; a_{2}>1\right)$ and the terminal value coefficient is significantly below one $\left(a_{3}<1\right)$. If the coefficients for all the three components are not significantly different from one $\left(a_{1}=1, a_{2}=1, a_{3}=1\right)$, the market is assumed to be efficient; therefore, it is assumed that the stock market incorporates both short-term and long-term firm value components into the price. Abarbanell and Bernard (2000) claim that the advantage of this accounting-based valuation model in comparison to other valuation models for the purposes of testing stock market myopia is that it allows estimating firm value in terms of the variables toward which investors, firms and managers are purported to behave myopically.

By applying this model, Abarbanell and Bernard (2000) and Bushee (2001) offer evidence suggesting that the American stock market underestimates long-term terminal value relative to book value and short-term earnings. However, by estimating abnormal returns, they do not find that the stock market agents have obtained profits from the mispricing of firm value, suggesting that mispricing could be explained by measurement error instead of myopic behavior. The measurement error hypothesis, however, conflicts with the empirical evidence of Black and Fraser (2002), Davies et al. (2014) and Miles (1993).

Abarbanell and Bernard (2000) analyzed the book value of equity as a short-term component in the test for myopic pricing (assuming that $a_{1}=1$ for non-myopic behavior). However, one can argue that the book value of equity is a mix of several measurement approaches of assets and liabilities, which includes historical costs and current values (such as fair value). Under fair value accounting, the value of assets and liabilities reflects, as definition, the present value of future outcomes. Moreover, under historical cost accounting, accounting figures of assets can be a proxy for future expected outcomes at the acquisition date. As a theoretical consequence, part of the residual future expected benefits can be reflected and incorporated in the book value of equity. This is especially true under ideal conditions, i.e., perfect and complete markets, no information asymmetry and no agency costs etc. As an empirical consequence, it is expected that $a_{1}=1$ for two reasons: (1) the linear and rational term-valuation and (2) the relevance 
and information content of accounting numbers. In both cases, a statistically significant $\mathrm{a}_{1}$ and a high $\mathrm{R}^{2}$ should be expected.

Although Bushee (2001) finds evidence of measurement error in the term-value decomposition, he argues that the model can be effectively used as a benchmark to compare firms and the different forms of market recognition of near- and long-term abnormal earnings. In particular, Bushee (2001) shows that transient investors not only put more weight on the short-term components of firm value, but also their ownership is associated with systematic mispricing of the firm value components.

In the Brazilian context, Portella (2000) and Ohlson and Lopes (2007) were some of the first to conceptually discuss the empirical validity of the residual income valuation (RIV) model and its adaptation to the Brazilian market, especially in accounting terms. Freire, Zatta, Dalmácio, Louzada, and Nossa (2005), Ferreira, Nossa, Ledo, Teixeira, and Lopes (2008), Almeida, Brito, Batistella, and Martins (2012), and Cunha, lara, and Rech (2014) empirically implemented the valuation model using Brazilian data. Specifically, Freire et al. (2005) indirectly analyze the RIV model by investigating the relationship between dividend behavior and abnormal earnings. Ferreira et al. (2008), on the other hand, compare the RIV model with discounted cash flow (DCF) and discounted dividend growth (DDM) models and conclude that RIV outperforms the two other valuation models in terms of valuation accuracy. Finally, Almeida et al. (2012) apply the valuation model to analyze public tender offers to acquire shares (PTO).

\section{The role of earnings persistence in firm valuation and time horizon}

In this paper, we assume that earnings persistence has two main implications for financial analysis and the contractual role of accounting numbers: first, more persistent earnings are likely to be a better input to valuation models; as a consequence, value estimates will be more accurate for firms with higher earnings persistence. Second, more persistent earnings are likely to proxy for long-term market and managerial time orientation; as a consequence, the weight on long-term performance (or the long-term value component) will be higher for firms with higher earnings persistence.

Typically, earnings persistence is the time-series parameter that measures the magnitude of the effect of permanent earnings innovations on expected future earnings. This parameter helps to explain the relation between earnings and firm valuation (Kormendi \& Lipe, 1987; Ohlson, 1995). Persistent earnings have been acknowledged as being valuable for earnings forecasts (Frankel \& Litov, 2009) and stock return predictions (Collins \& Kothari, 1989).
According to the RIV model, the value of the firm is influenced by abnormal earnings that follow an autoregressive process in which the parameter of earnings persistence indicates how sensitive the firm value is to earnings realization (Ohlson, 1995). In this regard, Dechow et al. (2010) suggest that firms with more persistent earnings have a more 'sustainable' earnings and cash flow stream, which work as more useful inputs into equity valuation models.

The second implication of earnings persistence is that it is a measure of long-term performance and managerial time orientation. One of the attributed reasons for myopic behavior is the information asymmetry with respect to long-term performance (Jacobson \& Aaker, 1993), which could be reduced by the extent to which the accounting series is persistent. Cheng, Subramanyam, and Zhang (2007) also emphasize the role of earnings persistence in leading capital markets to misprice current earnings when they misinterpret the persistence of earnings components.

Myopic behavior has generally been associated with the greater emphasis placed on short-term profits; Baber et al. (1998), however, indicate that this association depends on earnings persistence, so as a greater weight is placed on earnings persistence in executive compensation instead of current period earnings, this helps to mitigate the horizon problem, encouraging managers to look beyond the current period earnings and mitigating myopic behavior.

In the Brazilian context, few papers analyze the role of earnings persistence. The few exceptions are Coelho, Aguiar, and Lopes (2011), who analyze the relationship between earnings persistence, industry structure and market share, and Pimentel and Aguiar (2012), who analyze the persistence of quarterly earnings and its relationship with firm size and corporate governance levels. In terms of market recognition of accounting variables, Santos, Mol, Anjos, and Santiago (2013), Pimentel and Lima (2010b; 2010a), Neto, Galdi, and Dalmácio (2009), and Galdi and Lopes (2008) document statistically significant relationships between accounting data and stock prices (and stock returns) in the short and long term, suggesting relevant information content in the reported accounting numbers.

In this paper, the main measure of earnings persistence $(P E R)$ is the commonly used firm-specific first-order autoregressive regression of reported earnings, $X_{t}=\mathrm{a}+\beta X_{t-1}+\varepsilon$, where $X_{t}$ is the earnings per share in year $t$ and the autoregressive coefficient $\beta$ is the measure of earnings persistence. To classify each firm according to its earnings persistence, after having estimated the firm-specific $\beta$, we standardized the earnings persistence as $P E R_{i}=\beta-1 /(N-1)$, where $N$ is the number of firms in the sample. As a consequence, the firm with highest earnings persistence will have $P E R=1$, and the firm with lowest earnings persistence 
will have $P E R=0$. The rank approach also allows us to divide the sample into four portfolios according to the classification of firms into low, mean-low, mean-high, and high earnings persistence. We also test additional measures of earnings persistence described in the additional analysis section.

\section{Empirical implementation of the valuation models}

The first component of Equation 3 is the expected earnings. We apply a cross-section forecast model proposed by Fama and
French (2000) and adapted by Hou, Dijk, and Zhang (2012). Specifically, Kothari (2001) claims that the main advantage of the cross-sectional approach over time-series estimation is that the latter lacks power due to the few time-series observations of annual earnings available for most firms, and the crosssection models provide statistical power without imposing strict survivorship bias. Additionally, for the purposes of the present study, in which we are testing the ability of earnings persistence to serve as a proxy for long-term financial performance, the crosssectional approach can reduce the effect of potential endogeneity.

$$
E_{i, t+\tau}=\alpha_{0}+\alpha_{1} A_{i, t}+\alpha_{2} D_{i, t}+\alpha_{3} D D_{i, t}+\alpha_{4} E_{i, t}+\alpha_{5} N e g E_{i, t+\tau}
$$

where $E_{i, t+\tau}$ is the earnings of firm $\mathrm{i}$ in year $\mathrm{t}+\tau$ ( $\tau=1$ to 3), $D_{i, t}$ is the total assets, $D_{i, t}$ is the dividend paid, $D D_{i, t}$ is a dummy variable assuming 1 for dividend payers and o otherwise, $N e g E_{i, t}$ is a dummy for negative earnings assuming 1 for firms with negative earnings and o otherwise, and $\varepsilon_{i, t+\tau}$ is the forecast error for firm $\mathrm{i}$ in the year $t+\tau$.

We estimate Equation 5 by running the cross-sectional regressions suggested in Fama and French (1997). The regressions consider at least three years (1995 to 1997) of previous data with cumulative information up to 2013 . This means that the pooled regression in 2013 considers all periods of data (the 18 previous years). Thus, the forecast for 1995 to 1997 has the lowest lagged information content ( 3 years), and the forecast for 2010 to 2013 has the largest lagged information content (18 years).

After the estimation of expected earnings, the abnormal earnings are estimated by subtracting forecast earnings for year $t$ on the product of book value at $t-1$ and the discount rates. Discount rates (cost of equity capital) are estimated based on the Capital Asset Pricing Model (CAPM). First, we use the ex-post interbank deposit certificate (CDI) rate as a measure of risk-free credit. Specifically, the $C D I$ rate represents the standard rate of the biggest Brazilian financial institutions and (i) has similar magnitudes and time-series behavior to the basic interest rate fixed for Brazilian short-term government bonds and (ii) is the main credit risk-free reference for the money market and shortterm corporate bonds. In this paper, we consider the CDI at year $t$ as a flat proxy for the risk-free in $t+\tau$. Second, we use a $3 \%$ equity-risk premium consistent with Gonçalves Jr., Rochman, Eid, and Chalela (2011) and Claus and Thomas (2001), which found a market premium of $3 \%$ in the Brazilian market and several other international markets, respectively. Third, we estimate the market model beta by considering the lbovespa index as a proxy for the local market portfolio and by running ordinary least squares (OLS) regressions between the continuous monthly returns of firmspecific stock returns and the market index. When firms have dual shares traded in the market, we use the most liquid. Thus, we estimate the regression $R_{i}=a_{i}+\beta_{i} R_{m t}+e_{i}$, where $R_{i t}$ is the continuous compounded rate of return on the common stock of security $j, R_{m t}$ is the continuously compounded rate of return on the stock market index, $\beta_{i}$ is the long-term historical slope coefficient (beta) for firm $j$, and $e_{i t}$ is a normally distributed disturbance term. Hence, the firm-specific discount rate is estimated as $r_{i, t+\tau}=C D I_{t}+\beta_{i}[0.03]$.

Abarbanell and Bernard (2000) and Bushee (2001) use the difference between analyst forecast stock prices and book value of equity to describe the perpetuity of residual earnings after $\mathrm{t}$ periods ahead, the third component of Equation 3. In this paper, we follow the same methodology with one contextspecific difference: Brazilian market has one of the lowest analyst coverages in the world (Bae, Tan, \& Welker, 2008). Moreover, several recent studies show that analyst forecasts can be as biased as simple extrapolations (Bradshaw, Drake, Myers, \& Myers, 2012; Lacina, Lee, \& Xu, 2011). To address both issues (low analyst coverage and biased forecasts) and consistent with Fisher (1930) and Graham and McGowan (2005), we assume that future stock prices can be expressed with a price-level correction (inflation rate) plus a real growth output (based on gross domestic product (GDP) growth rate).

Additionally, consistent with clean surplus relationship (Ohlson, 1995), the expected book value at time $t+\tau$, is given by, $B V_{t+\tau}=B V_{t}+E_{t+\tau}-$ Div $_{T+\tau}$, where $B V_{t+\tau}$ is the book value in period $t+$ $\tau$, BVt is the book value in period $t, E_{t+\tau}$ is the earnings estimated according to Equation 5 and Div ${ }_{t+\tau}$ is the dividend paid by the firm, which is estimated by the firm-specific average of the payout ratio over the sample period. We therefore estimate the difference between forecasted price and forecasted book value after $\tau$ periods ahead as a proxy for long-term (terminal) value. 
Alternative assumptions about the discount rate and terminal value are also used in this paper and are described in the next sections.

\section{DATA, SAMPLE SELECTION AND VARIABLES ESTIMATION}

The analysis is based on public Brazilian companies listed on the Sao Paulo Stock Exchange (BM\&FBOVESPA) from 1995 to 2013. The length of the series and the number of firms are dictated by data availability conditioned to minimum firm-specific observations and minimum stock liquidity. The data are collected in the Economatica database and comprise the whole period of relative monetary stability - which began in 1995 with the "Real Plan". To avoid survivor bias, only the firms with a minimum of stock liquidity (one trade by month in the last three years was required) and with a minimum of eight consecutive annual observations are included in the analysis. Thus, the length of the time series of variables for each firm varies from 8 to 18 yearly observations. Financial institutions and insurance firms are excluded from the sample due to their very specific operational activity and financial statement structure.

The section criteria described above yielded a total of 176 firms. Thus, considering the periods and firms with data available, the analysis is based on 2,396 firm-year observations. The sample includes firms from different economic sectors (except financial institutions and insurance firms), and the market capitalization of these companies accounts for approximately $81 \%$ of the total market capitalization of BM\&FBOVESPA.

Stock prices $(P)$ and the stock market index are adjusted for subsequent stock splits and stock dividends, allowing for this adjusted figure to become the default price. Prices are based on the month's last trading day. Historical earnings $(X)$ for each company are also adjusted for subsequent changes in equity structures (stock splits, mergers and acquisitions, etc.), allowing for this adjusted figure to become the default earnings. Book value (b) is the published book value at the end of year $t$.

Discount rate is measured as described in previously and expected abnormal earnings for year $t$ are computed by subtracting forecast earnings for year $t$ on the product of book value at $t-1$ and the discount rates. In this paper, we consider variation in discount rates across firms and over time. The terminal value estimation considers the projection of the stock price in one, two, and three periods ahead conditionally to macroeconomic information available in the year $t$. Specifically, the forward stock price is estimated from the real GDP growth rate and inflation rate. These series are collected on the Banco Central do Brasil (Brazilian Central Bank) website and use yearly GDP growth at constant prices and the general price index (IPCA).

\section{EMPIRICAL FINDINGS}

The empirical tests are conducted in three main steps: first, we conduct the earnings forecast and the valuation implementation, and we analyze the role of earnings persistence as a determinant of valuation bias (errors). Second, we present the cross-sectional implementation of value decomposition (Equation 4) and analyze the role of earnings persistence as a proxy for the time-horizon. Third, we implement additional tests, extensions and alternative measures for the variables of interest.

\section{Abnormal earnings forecast and valuation outputs}

The first step in our analysis is the forecast of earnings over one, two, and three years using Equation 4. The earnings forecasts are conducted in a pooled cross-sectional regression (Fama \& Macbeth, 1973) for at least three years (1995 to 1997) of previous data and cumulative information up to 2013 (i.e., earnings forecasts in 2013 consider coefficients estimated using the entire time-series length). Panel A of Table 1 shows the descriptive statistic for the earnings forecast model; Panel B shows the coefficient estimates of the cross-sectional earnings model; and Panel $\mathrm{C}$ shows the distributional characteristics of forecasted earnings, abnormal earnings, and book value of equity.

The descriptive statistics in Panel A of Table 1 shows how heterogeneous the Brazilian firms are in terms of size and earnings formation. Some extreme negative earnings can be found, and more than $25 \%$ of the earnings sample observations are negative, which strongly interferes with earnings forecasts (toward negative earnings). Panel B shows the average coefficients of cross-sectional regressions. Consistent with the cross-section earnings forecast, the econometric models have, on average, a high adjusted coefficient of determination $\left(R^{2}\right)$, suggesting that the models can explain, on average, approximately $85 \%, 76 \%$, and $68 \%$ of earnings for one, two, and three years ahead, respectively. The lower explanatory power in long horizons is consistent with the well-documented higher forecast errors for longer horizons. Typically, the most relevant variable in forecast earnings is lagged earnings and dividends. The negative intercepts suggest that there are additional variables, not included in the model, that strongly influence earnings negatively. This effect seems to be related with macro variables such as exchange rate variations or an increase in interest rates because it tends to affect all variables in the model.

Once we have forecasted earnings for one, two, and three years ahead, we estimate the future book value of equity and the abnormal earnings by assuming the clean surplus relation $\left(b_{t+1}=b_{t}\right.$ $\left.+E_{t+1}-D_{t+1}\right)$. The abnormal earnings $A E$ are estimated considering the appropriate firm-specific discount rate; thus, $A E=E_{i, t+\tau}-r_{i t} b_{t+\tau-1}$, 
where $r$ is the discount rate adjusted by risk, varying over time to capture the current discount rate expectation. We assume that dividend payments follow a historical average captured in the mean firm-specific dividend yield. The distributional characteristics of all estimated figures are presented in Panel C of Table 1.

One relevant aspect documented in Panel C of Table 1 is that more than $50 \%$ of the sample have negative abnormal earnings. This means that, even if the firm generated positive earnings in a given year $t$, the return on equity (ROE) is not sufficient to cover the cost of equity capital in that year. In other words, more than half of the observations do not generate positive economic value added.

Those negative abnormal earnings are, in many cases, persistent along the period of analysis and, combined with the negative book value of equity, yielded negative values of equity. Negative market value has no meaning in economic terms. Thus, following Ali, Hwang, and Trombley (2003), to avoid the unrealistic assumption of long-run negative earnings expectations, we eliminate (firm-year) observations with negative market value estimates and negative book value of equity.

Table 1. Descriptive statistics and cross-sectional earnings regression from 1995 to 2013

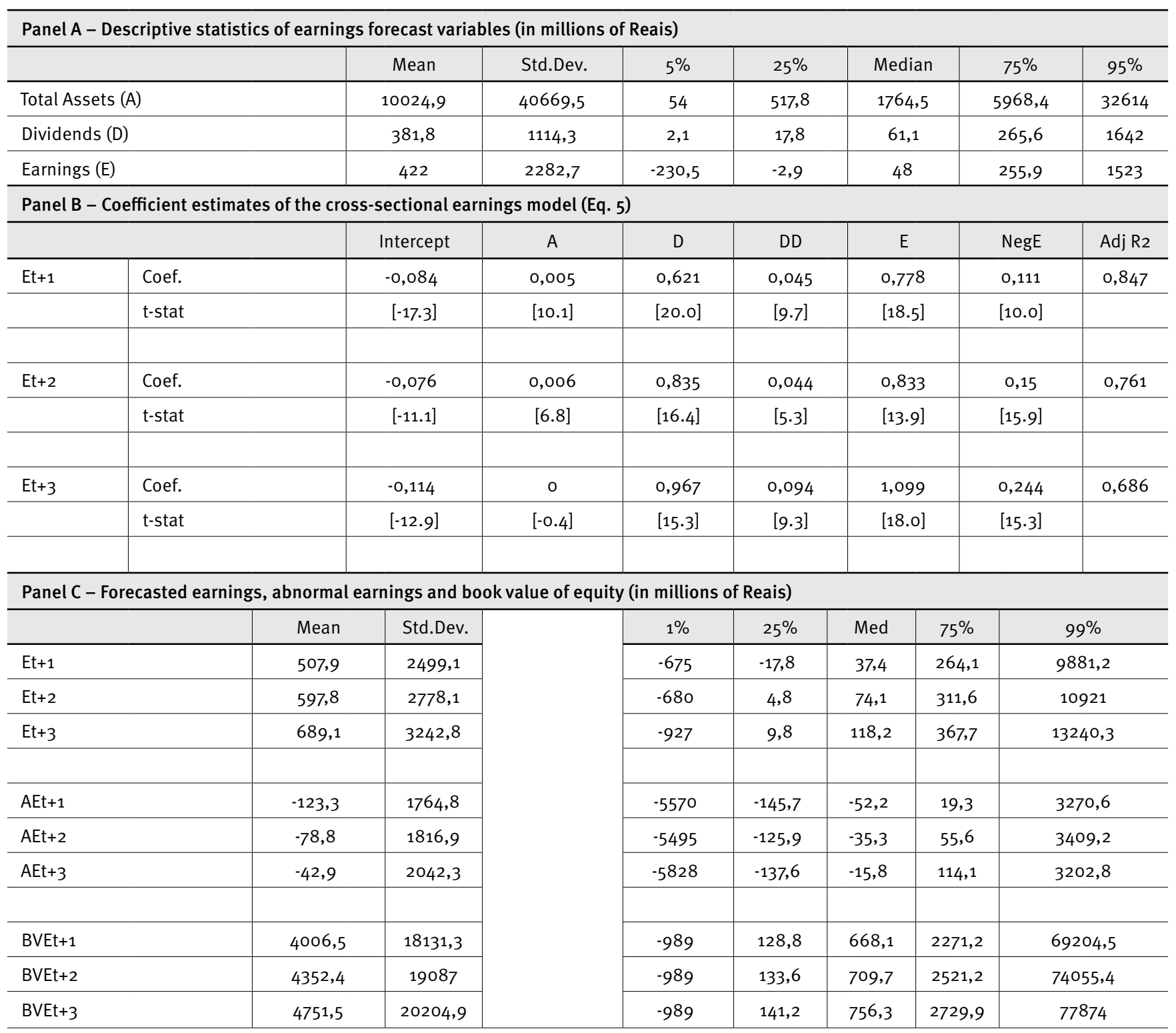

Note. Panel A: descriptive statistics for earnings forecast. Panel B: mean coefficients of cross-sectional OLS earnings forecast estimation based on Fama-MacBeth procedure where $A$ is the total assets, $D$ is the dividend paid, DD is a dummy variable assuming 1 for firms with dividend payment in year $t$ and o otherwise. E is the reported annual earnings and NegE is a dummy variable assuming 1 for negative earnings (loss) and o otherwise. Panel C: distributional characteristics of forecasted earnings ( $E$ ) forecasted abnormal earnings (AE), and book value of equity (BVE) in $t+1, t+2$ and $t+3$. 
Table 2. Term-value decomposition in one, two, and three years' horizons

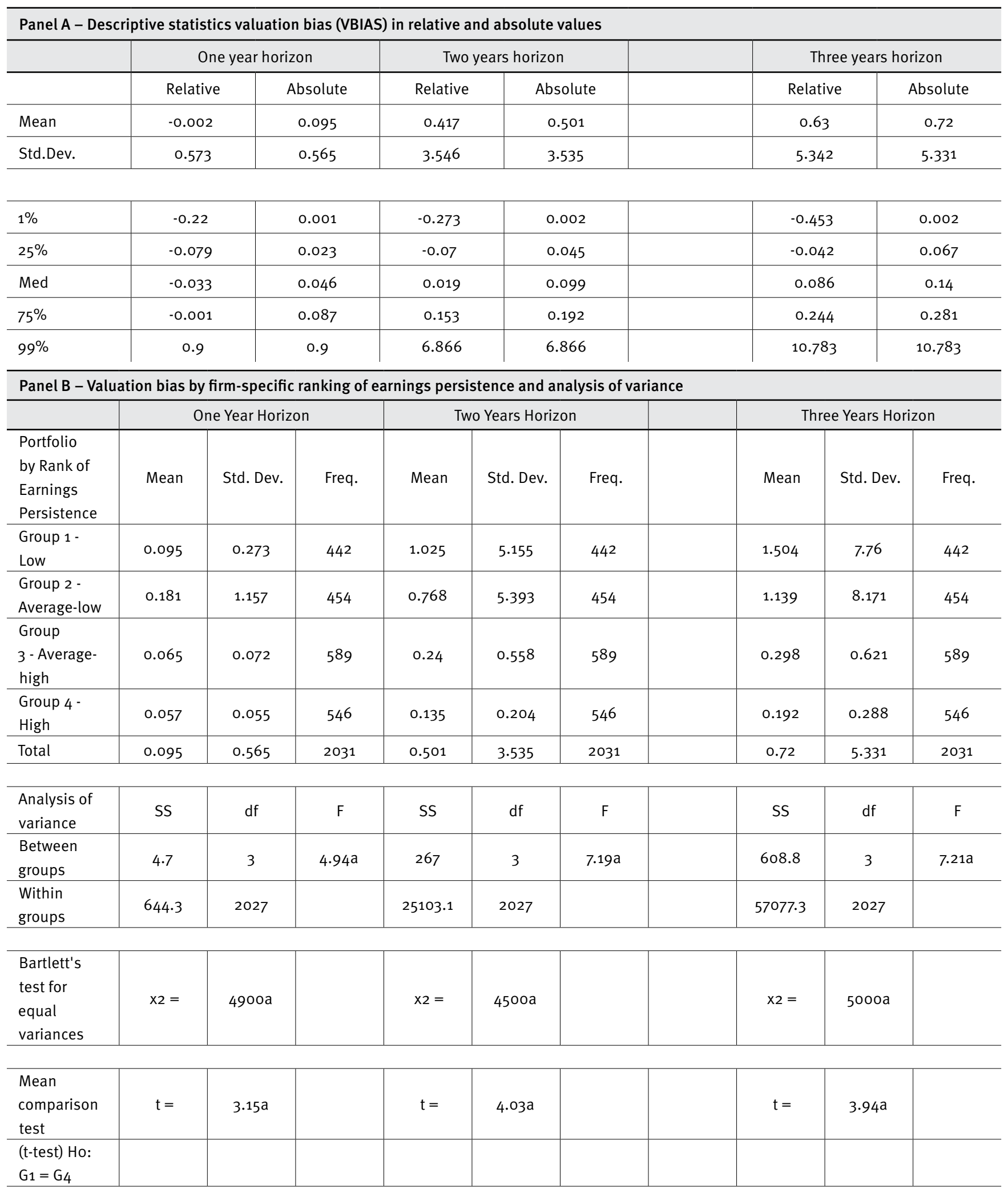

Note. Panel A describes the valuation bias (VBIAS) in relative and absolute values generally defined as the percentual difference between the estimated value of equity and the actual market value of equity. Variance tests analysis the equality across all portfolios and the mean test analyses the equality between portfolios 1 and 4 . a, b and c indicates statistical significance (rejection of equality) at $1 \%, 5 \%$ and $10 \%$ level, respectively 
After having eliminated firms with negative market value estimates (negative book value of equity and persistent negative abnormal earnings), we analyze the accuracy of the model implemented and the relationship between earnings persistence and forecast errors (bias). The elimination of firms with negative earnings is common in the literature. However, there is strong economic support for this: if firms have negative book values of equity that are not expected to revert in the future, the liquidation value of assets are a more relevant source of information than value estimates under a going concern assumption. The valuation model presented in Equation 3 is conducted with firmspecific valuation using the assumptions described previously. Following Shen and Stark (2013) and Heinrichs, Hess, Homburg, Lorenz, and Sievers (2013), we define the equity valuation bias (VBIAS) as the scaled difference between the estimated market value (MVEST) and the actual market value (MVACT); thus, $V B I A S_{i t}=\left(M V_{i t}^{E S T}-M V_{i t}^{A C T}\right) \mid M V_{i t}^{A C T}$. We consider the valuation bias in absolute and relative terms. Additionally, we divide the firms in the sample according to their rank of earnings persistence in four groups (portfolios) in which Group 1 represents the $25 \%$ of firms with lower earnings persistence and Group 4 the $25 \%$ of firms with higher persistence in earnings. The two intermediate groups, 2 and 3, have the firms with average-low and averagehigh earnings persistence, respectively.

Table 2 summarizes the valuation bias and presents analysis of the difference in valuation bias across the four groups of earnings persistence. The overall valuation bias is described in Panel A, and the valuation bias segregated by the persistence portfolio and variance analysis are presented in Panel B. The descriptive statistics displayed in Panel A show that valuation errors increase significantly when the time-horizon increases. In particular, considering the one-year horizon, the values estimated by the RIV model are, on average, slightly lower than the current value; however, more than $50 \%$ of the valuation errors are lower than $10 \%$ of the current (real) value. On the other hand, in the two- and three-year horizons, the values estimated by the RIV model are, on average, higher than the current value, and the valuation bias increases significantly from one to three years of explicit projection. With the threeyear horizon, the error interquartile range $(50 \%$ of the central observation) is approximately $30 \%$, but higher deviation can be found in the $25 \%$ of low and high valuation errors. The results show that the level of valuation accuracy is consistent with the previous literature; specifically, Heinrichs et al. (2013) recently found average RIV valuation errors of approximately $50 \%$ (in absolute terms) in the US market.

In Panel B, results comparing the valuation error across earnings persistence portfolios show that earnings persistence is a key element in valuation accuracy: firms with high persistence have significant lower valuation errors. Moreover, this is especially true when the time horizon increases. In the three-year horizon, the valuation error is, on average, higher than $100 \%$ (precisely $150.4 \%$ ), while the firms with high earnings persistence have an average valuation error of $19.2 \%$. The decreasing valuation errors are highly associated with the increase in earnings persistence for all four portfolios. The analysis of variance confirms that these differences in persistence portfolios have statistical significance at the $1 \%$ level.

The results of positive association between earnings persistence and valuation accuracy confirm the relevance of earnings persistence for valuation purposes and as a measure of earnings usefulness. The results documented in Table 2 show that high persistence earnings are a better input into the valuation process (Dechow et al., 2010). Moreover, these findings are consistent with evidence that considerations regarding high earnings volatility and low persistence of earnings bring substantial improvements to the prediction of earnings and valuation process (Dichev \& Tang, 2009).

After estimating all the components of the RIV model in Equation 3 and analyzing the relevance of earnings persistence to valuation accuracy, the next step in this paper is to check whether the stock prices are equally weighted between short- and longtime horizons and whether earnings persistence is related to valuation accuracy and long-term value components. These analyses are presented in the next section.

\section{Firm value decomposition: Level price regressions}

Our second procedure consists of the analysis of term-value components (Equation 4) and the adequacy of earnings persistence as a proxy for long-time orientation. According to Abarbanell and Bernard (2000), market efficiency predicts that in Equation $4, a_{0}=0$ and $a_{1}=a_{2}=a_{3}=1$. The alternative hypothesis (market myopia) is that, $a_{1}>1, a_{2}>1$, and $a_{3}>1$. However, according to the authors, the model specification in Equation 4 is subject to measurement error. In this regard, Bushee (2001) claims that even in the presence of measurement error, the model can be an effective benchmark to decompose value and compare timeorientation across firms.

In this paper, we test three different definitions of the shortterm horizon: one, two, and three years ahead. Evidently, if the earnings forecast and future prices are correctly estimated, there should not be significant differences between the explicit periods defined in one, two, or three years. However, with earnings 
surprises and price revisions, the corrections are incorporated in the long-term valuation components (Bushee, 2001). The results are displayed in Table 3, and they do not suggest shorttermism but that other variables that can explain stock price are not consistent with the accounting model. First, the intercept coefficient $a_{0}$ is assumed to be equal to zero, and it actually is equal to zero when the short-term horizon is defined as one and two years ahead. However, in the three-year horizon, the intercept is significantly different from zero, suggesting that other variables play an additional role in the longer-term horizon. Second, although the coefficients $a_{1}, a_{2}$ and $a_{3}$ are nominally close (and lower) to one, they are, in fact, statistically distinguishable from one at standard significance levels.
Unlike the previous literature (Abarbanell \& Bernard, 2000; Bushee, 2001), when the short-term horizon is defined as one year, the long-term value $\left(a_{3}\right)$ seems to play a more relevant role than short-term components, suggesting the opposite of shorttermism in the Brazilian market. When the time horizon increases to two and three years, news in earnings are incorporated into price, and the relevance of long-term components is diminished in favor of the short-term earnings component. In a three-year shortterm horizon, the short-term earnings are significantly more than the long-term value (more than three years). However, even after three years, the long-term component still plays a more important role in the Brazilian market than that documented in Abarbanell and Bernard (2000) and Bushee (2001).

\section{Table 3. Term-value decomposition in one, two and three years' horizons}



Nota. Term-value decomposition where BVE is the book value of equity. PVAB is the present value of abnormal returns during the short-term period, where short-term is defined earnings forecasted to one, two or three years ahead. PVTV is the present value of terminal value where the terminal value is the difference between market and book value of equity at one, two or three periods ahead.

a, b and $\mathrm{c}$ indicates statistical significance at $1 \%, 5 \%$ and $10 \%$ level, respectively.

The results documented in Table 3 are estimated under OLS regressions with White (1980) heteroskedasticity corrections. Hausman's test is conducted and suggests rejection of the null hypothesis that estimators under fixed and random effect are identical, and the Chow (F-) test for poolability rejects the joint null hypothesis of equal coefficients at standard significance levels. Nonetheless, we also estimate the equations under the Fama-MacBeth two-step approach, and the results are qualitatively the same, with the only difference in the smaller magnitudes of the intercept coefficient $a_{0}$ and the rejection of non-significance of the intercept in the three-year horizon (corroborating the hypothesis of $a_{0}=0$ in the three-year horizon as well). These additional results are available by request.

Although our results are different from those documented in Abarbanell and Bernard (2000) and Bushee (2001), they are consistent with those obtained for the Portuguese stock market (Coelho, 2010). To estimate the coefficients, Coelho (2010) also runs cross-sectional regressions for each individual year before calculating the mean coefficients across years (Fama-MacBeth procedure). His results do not favor the short-termism mispricing caused by market myopia. 
The next step in this paper is to analyze if part of the information content in earnings persistence is attributed to the longterm horizon. We follow Bushee (2001) and consider the benchmark of term-value components between firms, and we apply similar approaches by interacting the variable of interest with the term value components. Thus:

$$
P_{i t}=\alpha_{0}+\alpha_{1} B V_{i t}+\alpha_{2} \mathrm{BV}_{i t} * P E R_{i}+\alpha_{3} P V A B_{i t}{ }^{*}+\alpha_{4} P V A B_{i t} * P E R_{i}+\alpha_{5} P V T V_{i t}+\alpha_{6} P V_{T V} \text { * } P E R_{i}+\omega_{i t}
$$

Specifically, we analyze two interactions of earnings persistence (we also test additional measures of earnings persistence described in the additional analysis section). The first is rank-order earnings persistence $P E R^{R}$, ranging from zero to one. The second measure is based on a portfolio approach with a categorical variable assuming 1 to 4 according to the portfolio of low to high firm-specific earnings persistence. Firms in the first portfolio (1) are those with the lowest earnings persistence, and firms in the $4^{\text {th }}$ portfolio are those with highest persistence. The basic idea is that the higher the earnings persistence, the higher the extent to which current earnings innovation affects future earnings figures. Thus, the higher the earnings persistence, the higher the focus on the longterm components of earnings. In quantitative terms, one should expect that earnings persistence is significant and positively related to the long-term component and significant and negatively related to short-term components.

The empirical implementation of Equation 6 is conducted with the OLS approach, and considering White (1980), heteroskedasticity corrections and the results are presented in Table 4. The results do not support that earnings persistence is related with long-term components and, consequently, negatively related with short-term components over all term-horizon definitions (one, two, and three years).

\section{Table 4. Term-value components and earnings persistence in the three short-term horizon definition}

\begin{tabular}{|c|c|c|c|c|c|c|}
\hline \multirow[t]{3}{*}{ Eq. 6} & \multicolumn{6}{|c|}{$P_{i t}=\alpha_{0}+\alpha_{1} B V_{i t}+\alpha_{2} \mathrm{BV}_{i t} * P E R_{i}+\alpha_{3} P V A B_{i t} *+\alpha_{4} P V A B_{i t} * P E R_{i}+\alpha_{5} P V T V_{i t}+\alpha_{6} P V T V_{i t} * P E R_{i}+\omega_{i t}$} \\
\hline & \multicolumn{3}{|c|}{ Rank-order persistence (PERR) } & \multicolumn{3}{|c|}{ Four portfolios of persistence (PERP) } \\
\hline & $\begin{array}{l}\text { One year } \\
\text { horizon }\end{array}$ & $\begin{array}{c}\text { Two years } \\
\text { horizon }\end{array}$ & $\begin{array}{c}\text { Three years } \\
\text { horizon }\end{array}$ & $\begin{array}{l}\text { One year } \\
\text { horizon }\end{array}$ & $\begin{array}{c}\text { Two years } \\
\text { horizon }\end{array}$ & $\begin{array}{c}\text { Three years } \\
\text { horizon }\end{array}$ \\
\hline \multirow[t]{2}{*}{ Const. } & $0.190 a$ & $0.352 a$ & $0.412 a$ & $0.192 a$ & $0.356 a$ & $0.411 a$ \\
\hline & {$[5.1]$} & [4.9] & {$[4 \cdot 4]$} & {$[6.4]$} & {$[5 \cdot 5]$} & {$[4 \cdot 5]$} \\
\hline \multirow[t]{2}{*}{ BVE } & $0.954 a$ & $0.920 a$ & $0.955 a$ & $0.964 a$ & $0.939 a$ & $0.981 a$ \\
\hline & [79.2] & [35.3] & [30.8] & {$[57.4]$} & {$[27.4]$} & [23.1] \\
\hline \multirow[t]{2}{*}{$B V E \star P E R$} & $-0,002$ & $-0,015$ & $-0.121 a$ & $-0,003$ & $-0,008$ & $-0.03 b$ \\
\hline & {$[-0.1]$} & {$[-0.4]$} & {$[-2.6]$} & {$[-0.6]$} & {$[-0.8]$} & {$[-2.5]$} \\
\hline \multirow[t]{2}{*}{ PVAB } & 0,516 & 0,545 & 0,127 & 0,67 & 0,757 & 0,218 \\
\hline & [1.3] & {$[0.5]$} & {$[0.1]$} & [1.6] & {$[0.7]$} & {$[0.2]$} \\
\hline \multirow[t]{2}{*}{ PVAB*PER } & 0,048 & 1,114 & $2.228 b$ & $-0,042$ & 0,137 & 0,372 \\
\hline & [0.1] & [0.8] & [1.7] & {$[-0.3]$} & {$[0.4]$} & {$[1.1]$} \\
\hline \multirow[t]{2}{*}{ PVTV } & $1.032 a$ & $1.044 a$ & $0.883 a$ & $1.011 a$ & $0.995 a$ & $0.871 a$ \\
\hline & {$[46.4]$} & {$[17.5]$} & {$[14.6]$} & [46.5] & {$[14.1]$} & [12.2] \\
\hline \multirow[t]{2}{*}{ PVTV*PER } & $-0,006$ & $-0,014$ & 0,052 & 0,005 & 0,012 & 0,016 \\
\hline & {$[-0.2]$} & {$[-0.2]$} & {$[0.7]$} & [0.8] & {$[0.6]$} & [0.7] \\
\hline Obs. & 2031 & 2031 & 2031 & 2031 & 2031 & 2031 \\
\hline Clusters & 174 & 174 & 174 & 174 & 174 & 174 \\
\hline$F(6,173)$ & $1220000 a$ & $294678 a$ & $143464 a$ & $908989 a$ & $252087 a$ & $85003 a$ \\
\hline
\end{tabular}

Note. Term-value decomposition where BVE is the book value of equity. PVAB is the present value of abnormal returns during the short-term period, where short-term is defined earnings forecasted to one, two or three years ahead. PVTV is the present value of terminal value where the terminal value is the difference between market and book value of equity at one, two or three periods ahead. PER is standardized rank of earnings persistence based on AR(1) parameter of reported earnings.

a, b and c indicates statistical significance at $1 \%, 5 \%$ and $10 \%$ level, respectively. 
The results documented in Table 4 do not confirm the expectation of a negative effect of earnings persistence on short-term components and/or a positive effect on long-term components. One possible explanation presented by the literature is that market agents fail to fully recognize the implication of earnings persistence for future earnings (Bernard \& Thomas, 1990; Chen, 2013).

To reduce the effect of firms with average earnings persistence and potential cross-sectional misclassification, we run the price-level regression for the two extreme portfolios of $25 \%$ low (portfolio 1) and $25 \%$ high persistence (portfolio
4) firms. The results of portfolio comparisons are displayed in Table 5 and confirm the previous analysis by yielding coefficients that are not significantly different from low and high portfolios. Additionally, we consider the analysis (not reported) of two portfolios accounting for the $50 \%$ highest and lowest firms, and the results remain the same: no significant differences between term-valuation across firms with high and low earnings persistence. This means that, although earnings persistence plays a significant role in valuation accuracy, it does not have significant implications in measuring short- or long-term orientation in the valuation process.

Table 5. Term-value decomposition in one, two, and three years' horizons for high and low persistence portfolios

\begin{tabular}{|c|c|c|c|c|c|c|}
\hline \multirow[t]{3}{*}{ Eq. 4} & \multicolumn{6}{|c|}{$P_{j t}=\alpha_{0}+\alpha_{1} b_{t}+\alpha_{2} \sum_{\tau=1}^{T}(1+r)^{-\tau} E_{t}\left[X_{t+\tau}-r b_{t+\tau-1}\right]+\alpha_{3}(1+r)^{-T} E_{t}\left[P_{t+T}-b_{t+T}\right]+\omega_{j t}$} \\
\hline & \multicolumn{3}{|c|}{ Portfolio 1} & \multicolumn{3}{|c|}{ Portfolio 4} \\
\hline & $T=1$ & $T=2$ & $T=3$ & $T=1$ & $\mathrm{~T}=2$ & $T=3$ \\
\hline Const. (ao) & $-0.021 a$ & $-0.052 a$ & $-0.083 a$ & $0.060 a$ & $0.129 a$ & $0.216 a$ \\
\hline \multirow[t]{2}{*}{ BVE (a1) } & $1.045 a$ & $1.065 a$ & $1.071 a$ & $1.016 a$ & $1.031 a$ & $1.090 \mathrm{a}$ \\
\hline & [88.3] & [44.6] & [33.8] & [47.8] & {$[26.8]$} & {$[17.0$} \\
\hline \multirow[t]{2}{*}{ PVAB (a2) } & $0.791 a$ & $1.567 a$ & $1.833 a$ & $0.789 a$ & $1.672 a$ & $2.555 a$ \\
\hline & [18.1] & [17.0] & [10.6] & [11.6] & [8.8] & {$[6.4]$} \\
\hline Obs. & 442 & 2031 & 2031 & 546 & 546 & 546 \\
\hline$F(3,18)$ & 4307 & 867 & 495 & 1046,6 & 295 & 273,4 \\
\hline
\end{tabular}

Note. Variables definitions are presented before. Portfolio 1 represents the $25 \%$ of firms with lowest earnings persistence while portfolio 4 represents the $25 \%$ firms with highest earnings persistence.

a, b and c indicates statistical significance (different from zero) at 1\%, $5 \%$ and $10 \%$ level, respectively.

Overall, the results suggest that earnings persistence in Brazil has a direct impact on the accuracy of firm valuation in the sense that more persistent earnings are better inputs for valuation purposes. However, we fail to document evidence that earnings persistence is relevant in explaining the distribution of firms' equity value in short- and long-term components.

\section{ADDITIONAL ANALYSIS, ROBUSTNESS CHECKS AND LIMITATIONS}

Following Dichev and Tang (2009) and Frankel and Litov (2009), in this paper, we also conduct the tests described above by considering the persistence of earnings deflated by total assets where the persistence parameter is given by the firm-specific OLS regression of $E_{t+1}=a+\beta E_{t+\varepsilon}$ (where earnings is deflated by assets as a return on asset, ROA measure). The results under the "ROA persistence" framework are qualitatively the same.

One potential concern with long-term panels $(T \cdots \cdots \infty$ and $N$ finite) is related to strong non-stationary variables. Although the highest length of our time-series is 18 years, we tested for the existence of unity root in the panel for each variable. According to the structure of our data (unbalanced panel), we conducted Fisher-type tests using Dickey-Fuller tests (i) with and (ii) without time trends and (iii) with drift terms and the Phillips-Perron tests. Panel unit-root tests are used to test the null hypothesis $\mathrm{H}_{\mathrm{o}}: \rho_{\mathrm{i}}=$ 1 for all $i$ versus the alternative $H_{a}: \rho_{i}<1$. The results for all tests reject the null of $\rho_{i}=1$ for all $i$ except for book value of equity 
(BVE). Because the BVE of equity can be expressed in terms of market minus expectations of future benefits at present value (see Equation 2) and considering the relatively short term of the data, we assume that our results are not subject to spurious conclusions.

We also test additional common assumptions on the terminal value; specifically, we apply two additional measures for terminal value: first, we apply the current market-to-book value ratio over the estimated book value of equity at the end of time $T$ (period of explicit projection that varies from one to three years, as discussed previously); under this assumption, the market-tobook value remains constant over the periods, and the future book value estimation relies on the clean surplus concept. The final conclusions do not change, although the magnitudes of estimate coefficients are different. The second approach is based on the assumption that the last abnormal earnings estimated at time $T$ will be growth in perpetuity at different growth rates (we tested with $2 \%$ to $5 \%$ growth rates). The results are markedly different from those reported in this paper, especially because more than $50 \%$ of our sample presents negative abnormal earnings. Negative abnormal earrings in perpetuity provide a negative terminal value, which is inconsistent with positive market-to-book values. We assume that negative earnings decrease to zero at the growth rate estimation. The results show that, in those cases, the terminal (long-term) value loses its relevance in valuation. A possible alternative is to eliminate those observations (Ali et al., 2003); however, we view this as an unrealistic assumption because a great part of our sample has this characteristic.

With regard to the discount rate, we also estimate the cost of equity capital by considering $5 \%$ more and $5 \%$ less than the CDI rate, and the results do not change under different assumptions of the discount rate, and all additional results are available by request.

As discussed early in this paper, part of the residual future expected benefits can be reflected and incorporated in the book value of equity. As a consequence, the statistical significance of the coefficient $a_{1}$ in the empirical model (Equation 4 ) can be explained by two complementary reasons: first, the linear and rational term-valuation and, second, the relevance and information content of accounting numbers. While both can be theoretically consistent, we focus our analysis and interpretation on the first effect.

Typically, empirical studies consider that short-term orientation is a market conjecture (Abarbanell \& Bernard, 2000; Black \& Fraser, 2002; Davies et al., 2014). However, Bushee (2001) shows that myopia can be related with firm-specific characteristics, such as the structure of ownership and control, the investment horizon, size, and risk (idiosyncratic). Thus, we additionally investigate other potential determinants of mispricing of term-components; specifically, we analyze the well-accepted cross-sectional relations between size and idiosyncratic risk in the stock pricing by assuming that stock price can be myopically estimated by the market.

We expect short-term valuation to be a decreasing function of size and an increasing function of risk. These two variables are well documented in the literature as strong predictors of information environment and earnings quality (Dechow et al., 2010).

Idiosyncratic risk (RSK) is the ranked variance of monthly returns given by $T R K_{i t}=\left(V R a n q_{i t}-1\right) /(N-1)$, where VRanq denotes the rank position of total risk (i.e., variance of returns over 48 months) associated with a sample observation in year $t$, and let $\mathrm{N}$ denotes the number of observations in that year. Therefore, in a particular year, TRK is equal to zero for the firm with the smallest total risk and is equal to one for the firm with the highest total risk. Similarly, the proxy for size (SIZE) is the ranked total assets, in which SIZE $_{i t}=\left(\right.$ TAssets $\left._{i t}-1\right) /(N-1)$, where TAssets $_{i t}$ is the natural logarithm of total assets of a firm $i$ in year $t$. Although size can be correlated to other economic variables such as risk (negative relation), stock liquidity (negative relation) and information environment (positive relation), we expect a positive effect of size in the earnings response coefficient (ERC).

While the additional tests (the results are not reported due to space limitation, but they are available from the authors upon request) document a significant (positive) effect of risk in the short-term orientation, they fail to confirm any effect of size. Thus, we document that higher idiosyncratic risks are associated with higher short-term orientation. Overall, this result suggests that the valuation of firms with more volatile stock returns can be more oriented to short-term outcomes. We do not, however, define a causality relation: first, are stock prices more volatile because of short-term outputs, or are short-term outputs driven by market pressure as the market myopia literature suggests? The search for an answer is a possible extension for future research.

\section{CONCLUSION}

In this paper, we analyze the role of earnings persistence in valuation accuracy and as a proxy for long-term market orientation in the Brazilian market. Thus, we expect earnings persistence to have implications for both financial analysis and the contractual role of accounting numbers: (1) more persistent earnings are likely to be a better input to valuation models; and (2) more persistent earnings are likely to serve as a proxy for long-term market and managerial orientation; as a consequence, the weight of long- 
term performance (or long-term value component) will be higher for firms with higher earnings persistence.

Overall, results strongly support the relevance of earnings persistence in financial analysis and valuation because we document a negative relationship between earnings persistence and valuation errors (bias), which suggests that firms with higher earnings persistence provide more accurate value estimates than firms with low earnings persistence. However, although earnings persistence has been indicated as a long-term phenomenon (Baginski, Lorek, Willinger, \& Branson, 1999), which reduces the short-term characteristics of accounting earnings (Baber et al., 1998), we fail to document a significant relationship between earning persistence and long-term value orientation. These results are sensitive to different specifications of the discount rate, earnings persistence, and terminal value.

Additional results suggest that the short-term price components are positively associated with idiosyncratic risk (total risk), suggesting that high-risk firms have higher shortterm components (short-termism) than low-risk firms. As a consequence, firms with low risk tend to have a higher weight in long-term value than riskier firms.

Overall, these results have important implications for theory and practice. On the one hand, earnings persistence is likely to be an important parameter for valuation models because it is related to lower valuation errors, thus increasing valuation accuracy; the higher level of accuracy may be of interest for market agents who will have better information for their valuation decisions. On the other hand, earnings persistence may not be considered a measure that captures short termism on an organizational level, which means that although firms are not making decisions that have a more permanent effect on earnings, nor are they necessarily being myopic or short-termist; therefore, the use of such a measure for incentive purposes may not necessarily lead managers to think more of the long-term effects of their decisions, at least in the Brazilian context.

\section{Acknowledgments}

The authors thank the participants in the XII Encontro Brasileiro de Finanças 2012 (SBFIN Annual Meeting, 2012), the European Accounting Association Conference (EAA Conference, 2012), and the Copenhagen Business School Research Seminar (2014), as well as anonymous reviewers for helpful comments on early versions of this paper. Fundação de Amparo à Pesquisa do Estado de São Paulo (FAPESP, 12436-8/2013) is also gratefully acknowledged for granting the research with funding.

\section{REFERENCES}

Abarbanell, J., \& Bernard, V. (2000). Is the U.S. stock market myopic? Journal of Accounting Research, 38(2), 221-242. doi: $10.2307 / 2672932$

Ali, A., Hwang, L.-S., \& Trombley, M. A. (2003). Residual-income-based valuation predicts future stock returns: Evidence on mispricing vs. risk explanations. The Accounting Review, 78(2), 377-396. doi:10.2308/accr.2003.78.2.377

Almeida, J. E. F., Brito, G. A. S., Batistella, F. D., \& Martins, E. (2012). Análise dos modelos de avaliação Residual Income Valuation, Abnormal Earnings Growth e Fluxo de Caixa descontado aplicados às ofertas públicas de aquisição de ações no Brasil. Revista de Contabilidade e Organizações, 6(16), 3-19. doi:10.11606/rco. v6i16.52664

Baber, W. R., Kang, S.-H., \& Kumar, K. R. (1998). Accounting earnings and executive compensation: The role of earnings persistence. Journal of Accounting and Economics, 25(2), 169-193,. doi:10.1016/ So165-4101(98)00021-4

Bae, K.-H., Tan, H., \& Welker, M. (2008). International GAAP differences: The impact on foreign analysts. The Accounting Review, 83(3), 593628. doi:10.2308/accr.2008.83.3.593

Baginski, S. P., Lorek, K. S., Willinger, G. L., \& Branson, B. C. (1999). The relationship between economic characteristics and alternative annual earnings persistence measures. The Accounting Review, 74(1), 105-120.

Bernard, V. L., \& Thomas, J. K. (1990). Evidence that stock prices do not fully reflect the implications of current earnings for future earnings. Journal of Accounting and Economics, 13(4), 305-340. doi:10.1016/0165-4101(90)90008-R

Bhojraj, S., \& Libby, R. (2005). Capital market pressure, disclosure frequency-induced earnings/cash flow conflict, and managerial myopia. The Accounting Review, 80(1), 1-20.

Black, A., \& Fraser, P. (2002). Stock market short-termism: An international perspective. Journal of Multinational Financial Management, 12(2), 135-158. doi:10.1016/S1042-444X(01)00044-5

Bradshaw, M. T., Drake, M. S., Myers, J. N., \& Myers, L. A. (2012). A re-examination of analysts' superiority over time-series forecasts of annual earnings. Review of Accounting Studies, 17(4), 944-968. doi:10.1007/s11142-012-9185-8

Bushee, B. J. (1998). The influence of institutional investors on myopic R\&D investment behavior. Accounting Review, 73(3), 305-333.

Bushee, B. J. (2001). Do institutional investors prefer nearDterm earnings over long $\square$ run value?. Contemporary Accounting Research, 18(2), 207-246.

Chen, C. (2013). TimeDvarying earnings persistence and the delayed stock return reaction to earnings announcements. Contemporary Accounting Research, 30(2), 549-578. doi:10.1111/j.19113846.2012.01165.X

Cheng, M., Subramanyam, K., \& Zhang, Y. (2007). Earnings guidance and managerial myopia. Retrieved from http://dx.doi.org/10.2139/ ssrn. 851545

Claus, J., \& Thomas, J. (2001). Equity premia as low as three percent? Evidence from analysts' earnings forecasts for domestic and international stock markets. The Journal of Finance, 56(5), 16291666. doi:10.1111/0022-1082.00384 
Coelho, A. C., Aguiar, A. B. D., \& Lopes, A. B. (2011). Relationship between abnormal earnings persistence, industry structure, and market share in Brazilian public firms. BAR-Brazilian Administration Review, 8(1), 48-67. doi:10.1590/s1807-76922011000100005

Coelho, M. A. R. (2010). Existe sobrevalorização dos ganhos de curto prazo no mercado accionista português? (Master's thesis). Instituto Superior de Economia e Gestão, Universidade Técnica de Lisboa, Lisboa, Portugal.

Collins, D. W., \& Kothari, S. (1989). An analysis of intertemporal and crosssectional determinants of earnings response coefficients. Journal of Accounting and Economics, 11(2-3), 143-181. doi:10.1016/01654101(89)90004-9

Cunha, M. F., lara, R. N., \& Rech, I. J. (2014). 0 valor da perpetuidade na avaliação de empresas no Brasil. Revista de Contabilidade $e$ Organizações, 8(20), 17-31. doi:10.11606/rco.v8i20.55434

Davies, R., Haldane, A. G., Nielsen, M., \& Pezzini, S. (2014). Measuring the costs of short-termism. Journal of Financial Stability, 12, 16-25. doi:10.1016/j.jfs.2013.07.002

Dechow, P., Ge, W., \& Schrand, C. (2010). Understanding earnings quality: A review of the proxies, their determinants and their consequences. Journal of Accounting and Economics, 50(2-3), 344401. doi:10.1016/j.jacceco.2010.09.001

Demirag, I. (1995). Short-term performance pressures: Is there a consensus view? The European Journal of Finance, 1(1), 41-56. doi:10.1080/13518479500000007

Dichev, I. D., \& Tang, V. W. (2009). Earnings volatility and earnings predictability. Journal of Accounting and Economics, 47(1-2), 160181. doi:10.1016/j.jacceco.2008.09.005

Dikolli, S. S., \& Vaysman, I. (2006). Contracting on the stock price and forward-looking performance measures. European Accounting Review, 15(4), 445-464. doi:10.1080/09638180601101992

Fama, E. F., \& French, K. R. (1997). Industry costs of equity. Journal of Financial Economics, 43(2), 153-193. doi:10.1016/S0304405X(96)00896-3

Fama, E. F., \& French, K. R. (2000). Forecasting profitability and earnings. The Journal of Business, 73(2), 161-175.

Fama, E. F., \& Macbeth, J. D. (1973). Risk, return, and equilibrium: Empirical tests. The Journal of Political Economy, 81(3), 607-636.

Feltham, G. A., \& Ohlson, J. A. (1999). Residual earnings valuation with risk and stochastic interest rates. The Accounting Review, 74(2), 165183.

Ferreira, E. S., Nossa, V., Ledo, B. C. A., Teixeira, A. M. C., \& Lopes, A. B. (2008). Comparison of the residual income valuation, abnormal earnings growth and free cash flow models: An empirical study of the Brazilian capital market. Brazilian Business Review, 5(2), 143-162. doi:10.15728/bbr.2008.5.2.5

Freire, H. V. D. L., Zatta, F. N., Dalmácio, F. Z., Louzada, L. C., \& Nossa, V. (2005). Dividendos e lucros anormais: Um estudo nas empresas listadas na BOVESPA. Revista Contabilidade \& Finanças, 16(39), 4767. doi:10.1590/s1519-70772005000300005

Fisher, I. (1930). The theory of interest. New York: Macmillan.

Frankel, R., \& Litov, L. (2009). Earnings persistence. Journal of Accounting and Economics, 47(1-2), 182-190. doi:10.1016/j. jacceco.2008.11.008
Galdi, F. C., \& Lopes, A. B. (2008). Relação de longo prazo e causalidade entre o lucro contábil e o preço das ações: Evidências do mercado latino-americano. Revista de Administração, 43(2), 186-201. doi:10.1590/s0080-21072008000200006

Gonçalves, W., Jr., Rochman, R. R., Eid, W., Jr., \& Chalela, L. R. (2011). Estimando o prêmio de mercado brasileiro. RAC-Revista de Administração Contemporânea, 15(5), 931-954. doi:10.1590/S141565552011000500009

Graham, B., \& McGowan, B. (2005). The intelligent investor. New York: HarperCollins.

Heinrichs, N., Hess, D., Homburg, C., Lorenz, M., \& Sievers, S. (2013). Extended dividend, cash flow, and residual income valuation models: Accounting for deviations from ideal conditions. Contemporary Accounting Research, 30(1), 42-79. doi:10.1111/j.19113846.2011.01148.x

Hou, K., Dijk, M. A. Van, \& Zhang, Y. (2012). The implied cost of capital: A new approach. Journal of Accounting and Economics, 53(3), 504-526. doi:10.1016/j.jacceco.2011.12.001

Jacobson, R., \& Aaker, D. (1993). Myopic management behavior with efficient, but imperfect, financial markets: A comparison of information asymmetries in the US and Japan. Journal of Accounting and Economics, 16(4), 383-405. doi:10.1016/0165-4101(93)90033-c

Kormendi, R., \& Lipe, R. (1987). Earnings innovations, earnings persistence, and stock returns. Journal of Business, $60(3), 323-345$.

Kothari, S. P. (2001). Capital markets research in accounting. Journal of Accounting and Economics, 31(1-3), 105-231. doi:10.1016/S0165 4101(01)00030-1

Lacina, M., Lee, B. B., \& Xu, R. Z. (2011). An evaluation of financial analysts and naïve methods in forecasting long-term earnings. In K. D. Lawrence, R. K. Klimberg (Eds), Advances in Business and Management Forecasting, 77-101. Bingley: Emerald.

Laverty, K. J. (1996). Economic "short-termism": The debate, the unresolved issues, and the implications for management practice and research. Academy of Management Review, 21(3), 825-860.

Marginson, D., \& McAulay, L. (2008). Exploring the debate on short termism: A theoretical and empirical analysis. Strategic Management Journal, 29(3), 273-292. doi:10.1002/smj.657

Miles, D. (1993). Testing for short termism in the UK stock market. The Economic Journal, 103(421), 1379-1396. doi:10.2307/2234472

Neto, A. S., Galdi, F. C., \& Dalmácio, F. Z. (2009). Uma pesquisa sobre o perfil das ações brasileiras que reagem à publicação dos resultados contábeis. Revista de Contabilidade e Organizações, 3(6), 22-40.

Nickell, S., \& Wadhwani, S. B. (1987). Myopia, the'dividend puzzle', and share prices. CEPR Discussion Papers.

Ohlson, J. A. (1995). Earnings, book values, and dividends in equity valuation. Contemporary Accounting Research, 11(2), 661-687. doi:10.1111/j.1911-3846.1995.tboo461.x

Ohlson, J. A., \& Lopes, A. B. (2007). Avaliação de empresas com base em números contábeis. BBR-Brazilian Business Review, 4(2), 95-103.

Pimentel, R. C., \& Aguiar, A. B. (2012). Persistence of quarterly earnings: An empirical investigation in Brazil. BBR-Brazilian Business Review, 5(2), 38-54. doi:10.15728/bbrconf.2012.2

Pimentel, R. C., \& Lima, I. S. (2010a). Is the annual earnings response coefficient statistically significant in Brazil? Latin American Business Review, 11(3), 267-291. doi:10.1080/10978526.2010.513273

Pimentel, R. C., \& Lima, I. S. (2010b). Time-series properties of earnings and their relationship with stock prices in Brazil. Business and Economics Research Journal, 1(4), 43-65. 
Portella, G. (2000). Lucro residual e contabilidade: Instrumental de análise financeira e mensuração de performance. Caderno de Estudos, 12(23), 9-22. doi:10.1590/S1413-92512000000100001

Samuel, C. (2000). Does shareholder myopia lead to managerial myopia? A first look. Applied Financial Economics, 10(5), 493-505. doi:10.1080/096031000416370

Santos, M. A. C. D., Mol, A. L. R., Anjos, L. C. M. D., \& Santiago, J. S. (2013). Prices lead earnings in Brasil? Revista Contabilidade \& Finanças, 24(63), 243-256. doi:10.1590/s1519-70772013000300007
Shen, Y., \& Stark, A. W. (2013). Evaluating the effectiveness of model specifications and estimation approaches for empirical accountingbased valuation models. Accounting and Business Research, 43(6), 660-682. doi:10.1080/00014788.2013.840236

Sliwka, D. (2002). On the use of nonfinancial performance measures in management compensation. Journal of Economics \& Management Strategy, 11(3), 487-511. doi: 10.1111/j.1430-9134.2002.00487.x

White, H. (1980). A heteroskedasticity-consistent covariance matrix estimator and a direct test for heteroskedasticity. Econometrica: Journal of the Econometric Society, 48(4), 817-838. doi:10.2307/1912934 